\title{
Social investment Social Clinic Project Model
}

\author{
Dr. Hazem Mohammed Ibrahim Matter \\ Department of Social Planning \\ College of Social Work \\ Helwan University \\ Egypt \\ hazem_ebrahem@social.helwan.edu.eg
}


مجلة كلية الخذمة الاجتماعية للدر اسات و البحوث الاجتماعية - جامعة الفيوك 
Summary: The proposal of the Code of Ethics on practicing the profession of social work in Egypt has many advantages and did not cost the state anything, but it only needs legislation to take its validity and legal legitimacy, since state institutions and the private sector do not absorb the numbers that graduate each academic year from social Work colleges and institutes in Egypt, The proposal is not an invention or a catalogue, but a successful model in the countries that apply it, and the added value of the project is: eliminating the unemployment of social workers, investing the capacities of social workers in confronting and solving social problems, spreading social work in the geographical scope of Egyptian society, achieving social investment, and after interviewing a sample of community members in different geographical and cultural locations. In addition to studying and analyzing the content of the group of laws, regulations and decisions organized by the Union of Social Professions in Egypt, studying the international ethical document of social workers in 1976, studying the Ethical Charter of Social Workers (NASW) 1979,studying the draft code of ethics of the profession of Palestinian social workers and psychologists, and studying the ethical charter To practice social professions in the Kingdom of Bahrain 2009,andstudy the moral charter in Kuwait 2013, and in light of that the current project was developed, and the benefits of the project and the social benefit of it: eliminating unemployment, helping young graduates in social stability, facing many social problems, correcting social, achieving community awareness, confronting negative and extremist ideas, promoting the Egyptian family, helping the family court, Help juvenile court, ease the burden on state institutions, develop human resources, achieve proper social construction Achieving the goals of the social Work profession.

Keywords: Social investment, social clinic. 
First, the problem of study:

All countries, whether developed or developing, are interested in making various efforts to achieve the desired development, to reach the society that is the highest level of progress for the developed countries ,and the arrival of developing countries to a decent level of growth and progress to catch up with the developed countries and get out of the third world circle and suffer from under development, swell as in order to achieve the well-being of In this way, all countries, especially developing countries, and countries that are moving strongly towards development to catch up with developed countries, including Egypt, are interested in establishing and building a society on a sound basis by taking care of human development first, because it is the basis for achieving development and not community development without it, because it will bear the abuse and responsibility of the desired community development. The Egyptian society is considered to be one of the societies that strives to achieve comprehensive and sustainable development, and in this way seeks to develop its human resources to exploit and employ the enormous material resources it has, because human resources are the real strength of society, and it is the maker of development and its goal and its means, and the reforested society seeks to prepare this force, and there has become a clear interest from all developing countries at different levels and cultures necessary The development of human resources, where the development of these resources aims to achieve the desired change in terms of the optimal use of resources and association with the objectives of the society, and for you to achieve the comprehensive and sustainable development desired by the societies, the development of human resources must be developed because they are the target of development and its means, and the building of nations as soon as it depends on the development of these resources, through the preparation and the characteristics of good citizenship, and the development of capabilities and skills. Individuals are empowered to contribute to development, on the basis that the development of human resources aims to achieve the desired change in terms of optimal use of resources and association with the objectives of the society. This emphasizes the importance of the Private practice of social work, and the Private practice means that social workers under certain conditions work for themselves by providing a quality professional service and sometimes personal service to those who request and want it for a certain financial exchange, in other words, paid service, while the private practitioner is a social worker who practices the profession every or some time in his social clinic, and the problem of study can be 
formulated in: What is the Code of Ethics of practicing the profession for the social clinic project?

the importance of the study: Second

1- Increasing the number of unemployed social workers.

2- The advancement of human wealth can only be achieved by adopting a real confrontation with their unemployment.

3- Eliminating unemployment of social workers.

4- Take advantage of social workers in the face of social problems.

5- The spread of social work within the geographical scope of Egyptian society.

6- Achieving social investment.

7- The study of social problems is a realistic study.

Third, the objectives of the study:

1- Proposing the Code of Ethics on The Practice of Social Work.

2- Drafting of the social clinic project.

Fourth, the study's questions:

1- What is the social clinic project?

2- What is the proposal of the Social Work Act?

1- Social investment.

Fifth, the concepts of the study:

2- Social clinic.

Theoretical guides for the study:

1- General pattern theory: is one of the most basic theories that benefit us because it is one of the theoretical orientations on which the perspective of Generalist practice of social Work depends, and since this study is concerned with determining the roles of the general practitioner, this requires dealing with different Systems to achieve this, and therefore this theory is one of the most important theories.

2- Ecological pattern theory: It is also an important theme used by the perspective of Generalist practice in social work, which is useful in how to deal with different Systems of dealing, by identifying the contributions of the environment, because this theory is concerned with understanding the relationships and 
interactions between people and their environments, and emphasizing the mutual interaction between individuals and their environments.

3- Behavioral Theory: In order to know and determine how to deal with different types of behaviors and trends, especially negative, as well as to identify the triggers of wrong behaviors so that it can be changed to positive behavior, on the basis that behavior change is the result and response to an external exciter, as well as identify the methods that must be followed such as reinforcement, reinforcement, reward, learning and playing.

\section{Sixth methodology of research: \\ 1- Type of study:}

This study is a descriptive study that aims to propose the social clinic project Code of Ethics.

The method used:

The social survey method in the sample.

3- Preview plan:

University youth students of the Faculty of Social Work, graduates and researchers, and was surveyed by Intentional sample according to 5\% of the total number, and the sample type is a regular Intentional sample,

Study tool:

An electronic questionnaire, a sample interview of community members and models of different geographical and cultural locations was conducted, a sample interview of social Work students, and a sample interview from social Work researchers, Interview a sample of social workers, interview a sample of social workers, interview a sample of social workers, analyze the content of the set of laws, regulations and decisions organized by the Union of Social Professions in Egypt, and analyze the contents of the social work This charter was issued by the Association in 1979 and the content of the draft code of the profession of Palestinian social workers and psychologists, and the analysis of the content of the Ethical Charter for the practice of social professions in the Kingdom of Bahrain 2009. Analysis of the content sorority of the Code of Ethics in Kuwait and the Association of Social Workers, 2013, and analysis of the content of related scientific research, studies and articles.

Seventh, the results of the study: The study achieved its objectives, answered its questions and reached the proposed Code of Ethics as follows: 
Introduction: The proposal of the Code of Ethics on the practice of social Work has many advantages and did not cost the state one pound, only needs legislation to take its legal validity, since the profession of social Work in state institutions and the private sector does not accommodate the numbers that graduate each year from the colleges and institutes of social Work in Egypt, but reached the unemployment limit to pursue graduates of the master and doctoral degrees, and this of course helps to exacerbate the problem of unemployment in Egypt, the proposal is not invented or discovered but a successful model in the countries applied by the European countries and from The United States of Bahrain and the United Arab Emirates.

\section{Project name:}

Social clinic.

\section{The idea and objectives of the project:}

The application of social clinics in Egyptian society.

\section{Project value added:}

- Eliminating the unemployment of social workers.

- Take advantage of social workers in the face of social problems.

- The spread of social work within the geographical scope of Egyptian society.

- Social investment.

- The study of social problems is a realistic study.

\section{Description of the problem:}

- Unemployed social workers,20,000graduates almost nationwide.

- Intervention of non-specialists in the face of social problems.

\section{Customer:}

- Service provider (social worker).

- The beneficiary of the service (client) is all members of the community, groups and society as a whole. 


\section{Partners:}

- House of Representatives (legislation for the exercise of work)

- Ministry of Public Strength (issuance of social clinic permits).

- Ministry of Social Solidarity (to supervise and follow up the work of the social clinic).

- Union of Social Professions (to activate memberships).

- Social Work colleges and institutes (for training on the social clinic).

\section{Costs and income:}

- Costs on the state (none).

- Costs on the service provider (clinic equipment) 30000 pounds +1000 pounds per month + spare item.

- Revenue for the state (work permit fees +qualifying session fees + taxes).

- Revenue for the service provider (social clinic disclosure ticket fee)

- Eliminating the unemployment of social workers.

- Addressing social problems.

- Provide realistic and accurate social studies to decision makers.

\section{Application and practice:}

- Apply for a permit for the social clinic.

- Pass the course.

- Inspection of the location and location of the clinic.

- Professional practice.

\section{Implementation mechanisms:}

- Legislation passed by the House of Representatives.

- Announcement of legislation.

- Organizing training courses.

- Opening social clinics. 
- Follow-up social clinics.

\section{Challenges:}

- Failure to legislate the House of Representatives.

- Disapproval of the competent authorities.

- Disapproval of partners.

- Lack of community recognition.

\section{Scientific background:}

- The proposal of the Code of Ethics to practice the profession of social work as a practice specific in Egypt, presented by researcher Hazem Mohamed Ibrahim, to participate in the scientific conference of the Faculty of Arts at BeniSuef University, entitled Research Applications in the Field of Humanities and its Role in the Renaissance of Society, on April 4, 2017.

- Interview a sample of community members and models of different in different geographical and cultural locations.

- Interview a sample of social work students.

- Interview a sample of social Work researchers.

- Interview a sample of social work graduates.

- Interview a sample of social workers.

- Interview a sample of social work experts.

- The group of laws, regulations and decisions regulating the Union of Social Professions in Egypt.

- The International Ethical Document for Professional Social Workers, which was approved by the International Social Union at its 1976 meeting.

- The Ethical Charter of Social Workers (NASW), issued by the Society in 1979.

- Draft code of ethics for the profession of Palestinian social workers and psychologists.

- The Ethical Charter for The Practice of Social Professions in the Kingdom of Bahrain 2009. 
- The Moral Charter of the State of Kuwait and the Association of Social Workers 2013.

- Goals, principles, values and philosophy of social Work.

- Analysis of the content of related research, studies and scientific articles.

\section{Priority requests:}

Legislation from the House of Representatives, the legislature and the competent authorities for the eligibility of a social worker, which meets the requirements, to open a Private practice office for social Work and its consultation within a specific geographical scope in accordance with the principles, objectives and philosophy of the social

Work profession.

\section{Project benefits and social return:}

- Eliminating unemployment.

- Helping young graduates with social stability.

- Face many social problems.

- Correct socialization pathways.

- Achieving community awareness.

- Confront negative and extremist ideas.

- The advancement of the Egyptian family.

- Family court assistance.

- Help the juvenile court.

- Easing the burden on state institutions.

- Human resources development.

- Achieving proper social construction.

- Achieving the objectives of the social Work profession.

Proposed Code of Ethics:

Social Work, like other professions such as medicine, nursing, psychology, engineering, media, and other human professions that have their own professional ethical laws, regulates the process of practicing it, and this Code of Ethics arose through professional practice, so it develops from time to time, according to various factors including development, development, change and social change, and the development of science 
and knowledge on which the profession is based, where specialists in social Work sought to formulate general ethics such as maintaining the confidentiality of customer information, The customs and traditions of the community, confirmed by some legislation and laws governing the work, have included the fact that each profession in society has a set of ethics and principles governing the rules and methods of working with them and the conditions and specifications that must be met in their employees and practitioners of their activities, especially those that are directly related to the human being, including the profession of social Work. Social action is based on a set of human, religious and moral philosophies, in addition to achieving human development in its various aspects, which drives specialists in social work in all fields, to provide services aimed at human prosperity and self-realization, develop and organize the use of scientific knowledge related to human behavior and society, and develop resources to meet individual, collective and societal needs, in order to contribute to social justice and human rights, by focusing on developing one's own capacities and improving his reperformance.

The legal status of the Code of Ethics:

1. It is a guide to the ethical behavior of social workers.

2. It is also a professional covenant they make to themselves, to abide by.

3. This Code of Ethics reflects the fundamental values and ethics that must guide and control the professional practice of workers in the fields of social work.

4. This Code of Ethics provides general principles for guiding and rationalizing behavior in human, professional and personal situations.

5. This Code of Ethics provides the ethical and professional conduct of practitioners of the social work profession.

6. It is a dynamic, evolving and orderly framework for social work.

7. Help improve the quality of services provided to customers.

8. The Code of Ethics is an official document that can be relied upon to address and adapt legal issues that may occur between the different parties of the professional relationship.

Professional section: I swear to Almighty God that I respect the Constitution and the Code of Ethics and abide by all the provisions of the Code of Ethics of Private Practice. 
Provisions of the proposed Code of Ethics:

Part 1: The conditions and specifications of the social worker in charge of professional practice:

Article 1: A professional on his own account (private practice) must have

a scientific qualification in social work.

Article 2: The professional practitioner of social work must adhere to social values.

Article3: A professional practitioner must have the ability to establish strong social relationships.

Article 4: The general practitioner must be characterized by social intelligence, effective communication, objectivity, and emotional balance. Article 5: The professional practitioner must adhere to the philosophy, principles and ethics of the social work profession.

Article 6: The general practitioner can apply the social work skills he is trained in.

Article 7: The social worker should practice his work in secret in order to preserve customer information. Article 8: The social worker should update his information through courses, seminars, conferences and workshops.

Article 9: The social worker must comply with the professional duty. Article 10: The professional practitioner benefits the community by transferring experiences, skills and solutions.

Part 2: The ethical responsibilities of practitioners of the social work profession:

Chapter 1: The Personal Conduct of Social Workers: Article11: Freedom from all forms of religious, sectarian, political or class intolerance. Article 12: A social worker must be objective.

Article 13: Adherence to all principles, instructions and professional guidelines for social work.

Article 14: Taking into account the individual difference. Article 15: Respect for religious beliefs, feelings and social norms. Article 16: Professional intervention within the framework of the determinants of professional relationship.

Chapter 2: Ethical Responsibilities towards Customers:

Article 17: Customer interest is the first goal in the responsibilities of social workers.

Article 18: Forming a balanced professional relationship based on honesty, honesty and mutual respect with customers. 
Article 19: The professional practitioner does not exploit his relationships with clients for personal gain or personal, emotional and economic relationships.

Article20: Protecting the interests and rights of customers, respecting their privacy and maintaining the confidentiality of information. Article 21: Do not use recording devices or allow the presence of a nonprofessional person during the intervention process without the consent of customers.

Article 22: Distance from dealing with any form of discrimination between clients on any basis such as color, gender, age, religion, marital status.

Article 23: Commitment to total neutrality and objectivity when dealing with them.

Article 24: Failure to disclose secrets disclosed by customers without their consent, except for professional reasons permitted by Code of Ethics.

Article 25: To provide clients with accurate and complete information on the quality and volume of services available to them, to enable them to make appropriate informed decisions based on the freedom to choose from possible alternatives, to the success of the professional intervention

process.

Article 26: Maintaining the dignity of the client and not allowing him to be insulted or causing any moral or material damage to him. Article 27: Using scientific knowledge, professional skills and personal experiences to the fullest extent possible to serve the client.

Article 28: Seek professional advice from experts when it is in the interest of customers, while maintaining the principle of confidentiality.

Article29: The need to get the right hands-on training. Article 30: Ensuring that the professional practitioner obtains legal permission and professional qualification so that he or she does not fall under legal liability.

Article 31: Reduce the negative effects on customers from discontinuing the service.

Article 32: Ending the professional relationship with clients with professional methods followed in accordance with the rules, determinants and principles of the professional relationship in social work.

\section{Chapter 3: The ethical responsibilities of the practitioner towards} colleagues:

Article 33: It provides mutual respect, sincerity and cooperation about dealing with colleagues. 
Article 34: Commitment to dealing with colleagues with mutual trust and providing information and expertise.

Article 35: Taking care to perform tasks and responsibilities in cooperation with colleagues in a team spirit.

Article 36: Accuracy when cooperating with colleagues.

Article 37: Cooperation with colleagues should be official, not personal. Article 38: Following official and informal channels in dealing with and resolving disputes or disputes that can occur with colleagues.

Article 39: In the case of supervision or guidance to colleagues, professional conduct must be clear, objective and impartial and on clear and specific grounds and criteria.

Article 40: Avoid inciting the client not to cooperate with another colleague.

Article 41: Keeping secrets that are shared by colleagues during their professional relationships and transactions.

Article 42: Respect and cooperation for colleagues in other professions.

\section{Chapter 4: The ethical responsibilities of the practitioner towards} institutions:

Article 43: Not to disclose confidential information about the institutions through which the professional practitioner works.

Article 44: Using information and data related to the institutions through which he works for the purposes of study and research only for the benefit of the clients.

Article 45: The obligation to provide the institutions where the social worker works with the correct information.

Article 46: Use the resources of the organization for the purposes assigned to it only, and customer service.

Article 47: Professional advancement and the self-development of the social worker.

Article 48: Investing the resources available in the organization or that can be made available.

Article 49: Ensuring the harmony and compatibility of the employees of the organization to which he belongs

Article 50: to contribute to combating any form of discrimination in the treatment of the institution, and to help evaluate and develop the institution.

\section{Chapter 5: The ethical responsibilities of the practitioner towards the profession:}

Article 51: Affirming and supporting the status and dignity of the social work profession. 
Article 52: To maintain the philosophy, objectives, principles and ethics of the profession.

Article 53: Keenness to develop the scientific knowledge and professional skills of workers in the social work profession.

Article 54: Follow-up of emerging knowledge and methods developed to serve customers, the organization and the community.

Article 55: Working to develop the social policy industry, in order to promote the profession.

Article 56: If any worker in the social work profession commits an immoral act, appropriate measures must be taken through official channels, and the appropriate moral sanctions that may sometimes amount to a ban on the profession must be signed.

\section{Chapter 6: The ethical responsibilities of the practitioner towards the} community:

Article 57: Promoting professional methods that respect the dignity of society, its members and its groups.

Article 58: Make the right effort to provide resources, services and opportunities to customers.

Article 59: to contribute to the work of social justice.

Article 60: Conscious participation in preventing rumors and raising awareness of the danger of promoting them.

Article 61: Social awareness practice through all available channels. Article 62: Social solidarity in situations of crisis and community disasters.

Article 63: Contributing to social protection. Article 64: Empowering the primary care groups. Article 65: participation in social policy-making. Article 66: Contributing to the dissemination of the appropriate culture with regional and international developments. Article 67: Preserving religious values and the cultural and social environment.

Article 68: Commitment to the principles of professional practice of working with the community, as one of the ways of social work, in terms of principles, philosophy and mechanisms of action, and investing it to serve the community.

\section{Part 3: The General Principles:}

Article 69: The provisions of this Code of Ethics are reviewed on an ongoing basis. Article 70: This Code of Ethics is flexible and subject to amendment, deletion or addition. 
Article 71: The Code of Ethics takes into account recent trends in social work.

Article 72: This Code of Ethics is the basis for all professional practices of social workers in Egypt.

Article 73: Workers in the social work profession should be informed and adhere to this Code of Ethics.

Article 74: Anyone who violates one of the articles and provisions of the Code of Ethics shall be punished in accordance with the provisions of the Egyptian Constitution. 
References:

- AASW (1999). Code of ethics. Canberra: Australian Association of Social Workers.

- Abdelaziz Abdullah: Towards a vision to draft an Arab moral constitution for social work.

- Australian Code of Ethics (AASW, 1999).

- BASW (2003). Code of ethics for social work. Birmingham: British Association of Social Workers.

- British Moral Code (BASW, 2003).

- Canadian Code of Ethics (CASW, 1994).

- CASW (1994). Code of ethics. Ottawa: Canadian Association of Social Workers.

- Jamal, K. and Bowie, N. (1995). Theoretical consideration for a meaningful code of ethics. Journal of Business Ethics, 14.

- Kuwaiti Social Association, Ethical Charter of Social Workers in Kuwait, 2013.

- NASW (1999). Code of ethics of the National Association of Social Workers. Washington, DC: National Association of Social Workers.

- Reamer, F. G. (1997). Ethical standards in social work: The $N A S W$ code of ethics. Encyclopedia of Social Work, $\mathbf{1 9}^{\text {th }}$ edition. Washington, DC: National Association of Social Workers.

- Reamer, F. G. (1994). Social work malpractice and liability. New York: Columbia University Press.

- Reamer, F. G. (2000). 'Ethical Issues in Direct Practice', in P. Allen-Meares and C. Garvin (eds). The handbook of social work direct practice. California: Sage Publication, Inc.

- The Ethical Charter for Social Action of the National Association of Social Workers of the United States of America (NASW), 1979.

- U.S. Code of Ethics (NASW, 1999). 
مجلة كلية الخذمة الاجتماعية للدر اسات و البحوث الاجتماعية - جامعة الفيوك 